\title{
Kajian Aspek Pemasaran dan Aspek Proyeksi Keuangan dalam Upaya Pengembangan Usaha Di Isola Resort Hotel - UPI Bandung
}

\author{
Wishnu Wardhana \\ Sekolah Tinggi Pariwisata Bandung, Indonesia \\ Email: wishnuwardhana@stp-bandung.ac.id
}

\begin{abstract}
This study aims to assess the marketing aspect and the aspect of financial projections in Heritage Isola Resort Hotel as well as to analyze the influence of the dimensions of the product, place, price, and promotion of a business development plan to be undertaken and also evaluates the financial projections are measured using the method of Capital Budgeting with an evaluation tool discounted payback period net present value, internal rate of return, and profitability index in Isola Resort Hotel in Bandung. The method used in this research is survey method with descriptive explanations level by involving 46 respondents. Data collection techniques wing literature study, documentation studies, and field studies wing interviews and questionnaires. The data analysis technique used is qualitative analysis, quantitative analysis, and descriptive analysis. Qualitative analysis includes scores of respondents, and descriptive analysis. Results of research marketing activities in Isola Resort has generally shown good, with the results of the product dimension by $76.50 \%, 75.30 \%$ price dimension, a dimension of $80.20 \%, 71.50 \%$ of promotional dimension. As for the results of the evaluation based on the financial projections in Isola Resort Hotel is also in good condition. Projections of incomewas evaluated by using the method of capital budgeting by the calculation of the discowited payback period, net present value shows a positive result, the internal rate of return has the result is greater than the cost of interest rate of $12 \%$, and the profitability index has a positive outcome, le more than 1 . The findings of the study it can be concluded that the marketing aspect and the aspect of the financial projections is acceptable and to be implemented in Isola Resort business development efforts for the future.
\end{abstract}

Keywords: Marketing Mix, Financial Projection, Capital Budgeting.

\begin{abstract}
Abstrak
Penelitian ini bertujuan untuk menilai aspek pemasaran dan aspek proyeksi keuangan di Heritage Isola Resort Hotel serta untuk menganalisis pengaruh dimensi produk, tempat, harga, dan promosi rencana pengembangan bisnis yang akan dilakukan dan juga mengevaluasi proyeksi keuangan diukur menggunakan metode Capital Budgeting dengan alat evaluasi diskon payback period nilai bersih sekarang, tingkat pengembalian internal, dan indeks profitabilitas di Isola Resort Hotel di Bandung. Metode yang digunakan dalam penelitian ini adalah metode survei dengan tingkat penjelasan deskriptif dengan melibatkan 46 responden. Teknik pengumpulan data studi literatur sayap, studi dokumentasi, dan studi lapangan wawancara dan kuesioner sayap. Teknik analisis data yang digunakan adalah analisis kualitatif, analisis kuantitatif, dan analisis deskriptif. Analisis kualitatif mencakup skor responden, dan analisis deskriptif. Hasil kegiatan riset pemasaran di Isola Resort secara umum menunjukkan baik, dengan hasil dimensi produk sebesar 76,50\%, dimensi harga 75,30\%, dimensi 80,20\%, dimensi promosi 71,50\%. Adapun hasil evaluasi berdasarkan proyeksi keuangan di Isola Resort Hotel juga dalam kondisi baik. Proyeksi informasi dievaluasi dengan menggunakan metode penganggaran modal dengan perhitungan periode pengembalian discowited, net present value menunjukkan hasil positif, internal rate of return memiliki hasil lebih besar daripada biaya suku bunga $12 \%$, dan indeks profitabilitas memiliki hasil positif, lebih dari 1. Temuan penelitian dapat disimpulkan bahwa aspek pemasaran dan aspek proyeksi keuangan dapat diterima dan diimplementasikan dalam upaya pengembangan bisnis Isola Resort untuk masa depan.
\end{abstract}

Kata kunci: Bauran Pemasaran, Proyeksi Keuangan, Penganggaran Modal.

\section{A. PENDAHULUAN}

Adanya Peraturan Pemerintah (Perth) Kota Bandung untuk menaikkan Pendapatan Asti Daemh (PAD) pads sektor pariwisata, merupakan salah satu faktor pendorong pihak Isola Resort Hotel untuk melakukan penambahan asset. Peraturan Daerah tersebut ditangkap oleh pihak Isola Resort Hotel sebagai 
suatu peluang usaha untuk meningkatkan pendapatan (revenue) dengankonsep heritage hotel nantinya. Dengan adanya Peraturan Daerah tersebut akan menarik lebih banyak wisatawan untuk datang ke daerah Bandung, khususnya daerah Bandung Utara dan hal ini berdampak pula pada bertambahnya jumlah permintaan kamar maupun fasilitas konvensi di Isola Resort Hotel. Hal ini yang mendukung keputusan dewan direksi dan manajemen Isola Resort Hotel untuk melakukan penambahan asset berupa renovasi dan pengembangan 32 unit bungalow eks-perumahan dosen sebagai fasilitas heritage hotel. Keputusan dewan direksi dan manajemen Isola Resort Hotel tidak semata-mata hanya merujuk kepada Peraturan Daerah yang ada, akan tetapi didukung juga dengan pertumbuhan permintaan MICE di Isola Resort Hotel pada Triwulan 2011.

Melihat kondisi pariwisata di Bandung yang kian membaik dari tahun ke tahun, seluruh industri jasa pariwisata termasuk Isola Resort Hotel juga tidak mau kalah dalam meramaikan persaingan dalam memasarkan produknya yang mampu memenuhi kebutuhan wisatawan yang datang ke Kota Bandung. Isola Resort Hotel merupakan salah satu usaha akomodasi yang turut serta dalam bidang pariwisata khususnya dalam kegiatan MICE (meeting, incentive, convention, dan exhibition) di Kota Bandung Utara. Keberadaannya sebagai penyedia jasa penginapan, konvensi, serta pelayanan lainnya bagi wisatawan ternyata memberikan kontribusi bagi kegiatan pariwisata di Kota Bandung Utara. Isola Resort Hotel dipilih sebagai tempat penelitian, karena memiliki sejumlah unit analisis yang menunjang bagi penelitian ini.

Oleh karena perencanaan tersebut maka diperlukan pengkajian yang mendalam terhadap kelayakan pendirian Isola Heritage Hotel. Aspek penilaian yang dibutuhkan dalam penilaian kelayakan pendirian sebuah hotel menurut Husnan (2000:186) antara lain adalah:

\section{Aspek Pasar}

Berdasarkan atas jumlah wisatawan yang berkunjung untuk melakukan kegiatan MICE (Meeting, Incentive,Convention and Exhibition) yang berperan sebagai demand sedangkan jumlah fasilitas akomodasi yang tersedia untuk menangani pasar MICE tersebut adalah sebagai supply.

\section{Aspek Hukum,}

Aspek yang menjadi landasan hukum yang mendasari pembuatan izin dari usaha perhotelan.

\section{Aspek Teknis}

Meliputi bangunan yang ada untuk mendukung operasional hotel tersebut, perbaikan yang dilakukan untuk menjadikan bangunan ini menjadi representatif untuk dijadikan hotel, dan sistem pelayanan yang sesuai.

\section{Aspek Sosial Ekonomi}

Aspek yang menyangkut tentang dampak yang ditimbulkan dari perusahaan ini kepada masyarakat sekitarnya.

\section{Aspek Manajemen dan Sumber Daya Manusia}

Aspek yang menyangkut siapa dan bagaimana pelaksanaan operasional hotel tersebut nantinya.

\section{Aspek Keuangan}

Aspek yang menyangkut pendanaan yang diperlukan untuk mendirikan usaha perhotelan dan proyeksi pendapatan serta biaya-biaya dimana keputusan investasi dikatakan layak untuk dilaksanakan 
bilamana dapat memberikan keuntungan secara keuangan dan non keuangan. Secara keuangan dikatakan layak bilamana ada hasil lebih dari selisih besarnya hasil investasi terhadap biaya investasi.

Berdasarkan keenam aspek tersebut, penelitian yang dilakukan oleh penulis ini lebih menekankan kepada aspek pemasaran serta proyeksi aspek keuangan dikarenakan unit analisis yang mendukung untuk dilaksanakannya kajian pada kedua aspek tersebut dan kondisi objek penelitian yang membutuhkan pengkajian lebih mendalam pada aspek pemasaran dan aspek keuangan.

Analisis yang lazim dilakukan untuk menilai kelayakan sebuah usaha hotel dalam hal investasi adalah Capital Budgeting, namun demikian konsep capital budgeting masih belum banyak diterapkan oleh perusahaan sebagai alat analisis terhadap penilaian kelayakan investasi perusahaan. Dimana memperhatikan secara adil ekspektasi penyandang dana. Tidak seperti ukuran kinerja konvensional, konsep Capital Budget dapat berdiri sendiri tanpa perlu analisa perbandingan dengan perusahaan sejenis ataupun membuat analisa kecenderungan (trend). Pengertian Capital Budget menurut Schmidgall (1997:413) adalah "Capital Budgeting is the process of determining the amount to spend on fixed assets and which fixed assets to purchase".

Capital Budget berusaha mengukur nilai tambah yang dihasilkan perusahaan dengan memperhatikan biaya modal yang meningkat, karena biaya modal menggambarkan risiko perusahaan. Metode Capital Budget sesuai dengan kepentingan para investor dikarenakan pars investor memfokuskan pada prospek keuntungan di masa yang akan datang dan perkembangan selanjutnya untuk mengetahui jaminan investasinya. Selain itu, jika suatu perusahaan dapat menciptakan nilai tambah bagi pars investor, berarti mereka mendapatkan pengembalian yang lebih besar dibandingkan pada saat mereka beiinvestasi.

Adapun beberapa model untuk pengukuran kelayakan suatu investasi yaitu dengan metode Capital Budgeting menurut Chatfield dan Dalbor (2005:205) adalah sebagai berikut:

1. Profitability Index (PI)

Profitability Index is constructed by taking ratio the ratio of the benefits to the cost.

2. Payback Period (PP)

Payback Period is the amount of time required for the net cash flows to recover the net investment. If the calculated payback period is equal to or less then payback objective then the project is accepted.

\section{Net Present Value Model (NPV)}

Net present value is the sum of the present values of the net cash flows discounted at the required rate of return minus the net investment, the project accepted if the net present value is equal to or greater than zero.

\section{Internal Rate of Return (IRR)}

IRR model is the rate of return of causing the project net present value to equal zero, a project internal rate of return is compared to the project required rate of return. If the internal rate of return exceeds the required rate of return, the project is acceptable."

Berdasarkan penelitian intemasional yang dilakukan oleh Project Development Assistance Center Regional Development Council XI, Davao City (2002) dengan penelitian tentang studi kelayakan dukungan infrastruktur pada Program Ekonomi diKota Sarangani, Davao Del Sur, Filipina. Dari hasil penelitian diketahui bahwa biayaproyek adalah 48,88 juta peso dengan deskripsi proyek adalah pengembangan 
kompleks pelabuhan di Barangay Mabila, reklamasi daerah yang dekat dengan pantai,penambahan dan peningkatan dermaga dan jalan yang melintasi daerah rawa-rawadan pembangunan beberapa fasilitas tambahan seperti gedung administrasi, terminal penumpang, rumah makan, kamar yang nyaman dan ruang jaga. Dari hasil kelayakannya dapat diketahui bahwa dari sektor public dengan NPV Keuangandengan 12\% IR adalah - 22 juta peso, IRR 0,5\%, NPV ekonomi dengan 15 SDR adalah 139,2 juta peso dan IRR ekonomi $70 \%$ sedangkan untuk sektor privat dapat diketahui NPV dengan 16 IR sebesar 7,1 juta peso dan IRR 25,06 \%.

Arya Wijaya (2009) menyatakan dari penelitian tentang studi kelayakan penambahan bungalow pada PT Sari Ater adalah dari aspek pasar dan pemasaran dimana potensi penambahan bungalow pada PT Sari Ater yang cukup besar dapat dilihat dari tingkat hunian bungalow pada tahun 2005 sampai 2008, perniintaan biro perjalanan rekanan dan tingkat kunjungan wisatawan ke Sari Ater Resort. Positioning perusahaan ditentukan berdasarkan diferensiasi produk, jasa, personil dan citra, dengan pangsa sasaran dan target penjualan yang ditetapkan oleh pemegang saham agar memberikan keuntungan investasi, dengan segmentasi dan target pasar perusahaan adalah wisatawan yang berkunjung berdasarkan data historis yang mengalami peningkatan dari tahun ketahun. Strategi pemasaran yang digunakan ialah mempertahankan tingkat kepuasan yang tinggi, relationship marketing dan penyiapan produk komplementer dengan konsep one stop visiting. Strategi penetapan harga yang digunakan adalah perceived value pricing yaitu harga ditentukan oleh kesan pembeli terhadap produk yang ditawarkan. Hasil yang diperoleh dari penelitian dapat diketahui dari aspekkeuangan dim ana payback period investasi bungalow selama 5 tahun, tergolong menguntungkan karena payback period nya lebih pendek daripada yang diisyaratkan oleh pemilik modal yaitu 8 tahun, NPV positif dan lebih besar daripada nol sebesar Rp.9.317.999.029,- menunjukkan bahwa investasi penambahan bungalow akan meningkatkan keuntungan pemilik modal, PI sebesar 2,07 lebih besar dari 1, menunjukkan bahwa usulan investasi bungalow tersebut dapat diterima, IRR sebesar $26,11 \%$ lebih besar daripada biaya modal yang dipandang layak oleh pemilik modal sebesar $15 \%$. Hal ini menunjukkan bahwa rencana investasi tersebut dinilai menguntungkan, ARR sebesar 37,76\% lebih besar daripada patokan ARR yang ditentukan investor sebesar $15 \%$ sehingga dari segi profitabilitas, proyek investasi tersebut layak untuk dilaksanakan dan basil analisis sensitivitas menunjukkan bahwa variabel pendapatan sewa bungalow merupakan variabel yang sangat peka terhadap keberhasilan rencana investasi penambahan bungalow.

\section{B. METODE PENELITIAN}

Jenis penelitian yang digunakan dalam penelitian ini adalah jenis deskriptif analitik. Jenis deskriptif digunakan untuk tujuan membuatdeskripsi, gambaran secara sistematis, faktual, dan akurat mengenai fakta-faktaserta sifat dan hubungan denganfenomena yang diselidiki. Penelitian deskriptif yang dilakukan adalah dengan pendekatan studi survei dimana data yang diperoleh selama penelitian tersebut diolah, dianalisis serta diproses lebih lanjut berdasarkan teori yang telah dipelajari. Hal ini bertujuan untuk memperoleh deskripsi gambaran tentang aspek pemasaran yang memiliki empat variabel yaitu produk, harga, tempat, dan promosi. Kemudian untuk memperolehgambaran tentang aspek keuangan yang juga memiliki empat sub variabel yaituprofitability index, payback period, net present value, dan internal rate of return. Kedua aspek tersebut kemudian akan dinilai kaitannya dengan pengembangan usaha yang akan dilakukan oleh pihak PT. Isola Resort Hotel.

Teknik pengumpulan data, menggunakan studi Kepustakaan, Studi dokumentasi secara langsung, Studi lapangan pemasaran dan kinerja keuangan. Studi ini dilakukan dengan mencari sumber data melalui buku, literatur, referensi, maupun hasil penelitian dikumpulkan diperoleh dari subjek sejenis 
yang berkaitan denganmasalah yang diteliti. Studi dokumentsai secara langsung dengan diteliti secara langsung adalah mempelajari naskah, laporan, dokumen yang berhubungan dengan masalah yang sedang diteliti. Sementara studi lapangan pemasaran dan kinerja keuangan untuk mengumpulkan data dan informasi yang diperoleh secara langsung dilokasi penelitian dengan menggunakan cara sebagai berikut:

\section{Wawancara}

Wawancara menurut Cahyono (2006:40) adalah : "Proses interaksi dan komunikasi untuk memperoleh keterangan untuk tujuan penelitian dengan cara tanya jawab sambil tatap muka dengan menggunakan panduan wawancara". Penulis melakukan pembicaraan atau Tanya jawab secara langsung dengan Marketing. Coordinator dan Accounting Manager Isola Resort Hotel sesuai dengan masalah yang dibahas sehingga data yang diperoleh dapat dipertanggungjawabkan kebenarannya dan relevan dengan permasalahan yang diangkat.

\section{Observasi}

Penulis melakukan pengamatan secara langsung terhadap objek yang diteliti. Observasi menurut Kusmayadi dan Sugiarto (2000:84) adalah : "Cara pengumpulan data dengan menggunakan jalan mengamati, meneliti, atau mengukurkejadian yang sedang berlangsung". Alasan penulis melakukan observasi karena datanya bersifat fakta sesuai keadaan sebenarnya memiliki keuntungan karena data yang segar dalam artian data yang dikumpulkan diperoleh dari subjek pada saat terjadinya tingkah laku dankeabsahan alat ukur dapat diketahuiditeliti secara langsung adalahlaporan keuangan yang berhubungandengan keputusan investasi yang erat hubungannya dengan kinerja yang ada di Isola Resort Hotel.

\section{Kuesioner/Angket}

Teknik pengumpulan data melalui : penyebaran seperangkat daftar pertanyaan tertulis kepada responden yang menjadi anggota sampel penelitian yaitu potential buyer untuk membeli produk Isola Resort Hotel. Angket yang digunakan dan disebarkan pada responden merupakan angket yang disusun dengan memberikan altematif jawaban yang disediakan oleh peneliti. Dengan menggunakan angket tertutup sebagai teknik pengumpulan data akan mempermudah peneliti dalam melakukan analisis data dari seluruh angket sehingga dapat menghemat waktu. Pertanyaan dalam angket dibuat dalam bentuk pertanyaan, dan setiap altematif diberi nilai dengan membeli skala Likert, yaitu sebagai berikut:

Tabel 1: AlternatifJawaban Berdasarkan Skala Likert

\begin{tabular}{|c|c|c|c|c|c|}
\hline $\begin{array}{l}\text { Alternatif } \\
\text { Jawaban }\end{array}$ & $\begin{array}{c}\text { Sangat } \\
\text { Setuju }\end{array}$ & setuju & $\begin{array}{c}\text { Ragu- } \\
\text { Ragu }\end{array}$ & $\begin{array}{l}\text { Tidak } \\
\text { Setuju }\end{array}$ & $\begin{array}{c}\text { Sangat } \\
\text { Tidak } \\
\text { Setuju }\end{array}$ \\
\hline Positif & 5 & 4 & 3 & 2 & 1 \\
\hline Negatif & 1 & 2 & 3 & 4 & 5 \\
\hline
\end{tabular}

Sumber : Sugiyono (2008:87)

a. Uji Validitas 
Validitas adalah suatu ukuran yang menunjukkan tingkat-tingkat kevalidan atau kesahihan suatu instrumen. instrumen yang valid adalah alat ukur yang digunakan untuk mendapatkan data yang valid dan dapat digunakan untuk mengukur apa yang hendak diukur (Sugiyono, 2004:220).

Validitas yang digunakan adalah dengan menggunakan validitas konstruk, dengan validitas konstruk ini dapat diketahui komponen-komponen sikap atau sifat yang akan diukur dengan tes tersebut, pengujian validitas konstruk dapat dilakukan dengan dua cam yaitu pengujian validitas setiap butir pertanyaan dan pengujian validitas melalui analisis regresi terhadap instrumen.

Setelah kita mendapatkan basil dari jawaban responden maka jawaban tersebut kita hitung korelasi antar masing-masing pertanyaan dengan skor total yang menggunakan iumus korelasi Product Monrent s ebagai berikut:

$$
r_{Y X}=\frac{n\left(\sum X Y\right)-\left(\sum X\right)(\Sigma Y)}{\sqrt{\left[n \Sigma X^{2}-\left(\sum X\right)^{2}\right]\left[n \Sigma Y^{2}-(\Sigma Y)^{2}\right]}}
$$

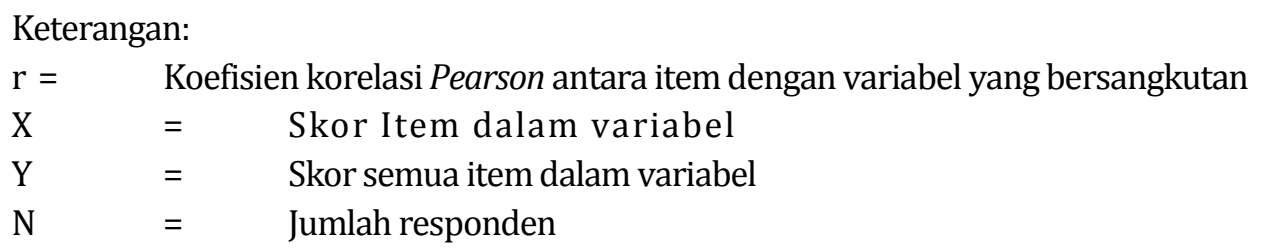

Dasar pengambilan keputusan:

- Jika $r$ positif, serta $r=0,30$ maka item pemyataan tersebut valid.

- Jika r tidak positif, serta $\mathrm{r}=0,30$ maka item pernyataan tersebut tidak valid.

b. Uji Reliabilitas

Reliabilitas adalah derajat ketepatan, ketelitian atau akurasi yang ditujukan oleh instrumen pengukuran. Instrumen yang re liabel berarti instrumen tersebut bila digunakan beberapa kali untuk mengukur obyek yang sama, akan mengahasilkan data yang sama. Suatu kuesioner dikatakan reliabel (andal) jika jawaban seseorang terhadap pertanyaan adalah konsisten. Pengujian reliabilitas instrumen dapat dilakukan secara ekstemal maupun internal. Secara eksternal pengujian dapat dilakukan dengan test-retest (stability), equivalent dan gabungan keduanya. Secara internal consistency dapat diuji dengan menganalisis konsistensi butir-butir yang ada (Sugiyono, 2004:221). Reliabilitas mengalamatkan variasi jawaban yang berbeda yang digunakan sebagai instrument pengukuran. Biasanya ini dievaluasikan dan disebut sebagai Homogenitas Intern, melalui koefisien Alpha Cronbach. Koefisien Alpha Cronbach merupakan suatu keandalan alat ukur. Suatu kuesioner dikatakan reliabel (andal) jika jawaban seseorang terha dap pertanyaan adalah konsisten. Koefisien ini secara teoritis berkisar antara 0 koefisien 1 belum pernah ada dam koefisien yang kurang dari 0 (negatif) tidak ada artinya karena interpretasi reliabilitas selalu mengacu pada koefisien yang nilainya 1, koefisien yang mendekati 1 menunjukkan tingkat konsistensi yang tinggi. Metode yang digunakan untuk menguji keandalan alat ukur dalam penelitian ini adalah menggunakan Metode Crronbach(Alpha/Reliability Analysis), berikut ini rumus koefisien Alpha (Supranto, 1997:60) :

$30 \mid{ }_{\mathrm{Jl}} \alpha=\left[\frac{k}{k-1}\right]\left[1-\frac{\sum \sigma_{b}{ }^{2}}{\sigma_{\imath}{ }^{2}}\right] \overline{\text { alitas dan Perjalanan, Volume } 1 \text { Nomor 1, 2017: 25-35 }}$ 
Keterangan :

$\begin{array}{lll}\mathrm{a} & : & \text { nilai reliabilitas. } \\ \mathrm{k} & : & \text { banyaknya butir pertanyaan. } \\ \text { Eab Z } & : & \text { jumlah varians butir. } \\ \mathrm{E}_{\mathrm{a}} & : & \text { jumlah varians total }\end{array}$

Dimana jumlah butir variansi dicari terlebih dahulu dengan cara mencari nilai varians tiap butir, dengan menggunakan rumus varian sebagai berikut :

$$
\alpha=\left[\frac{k}{k-1}\right]\left[1-\frac{\sum \sigma_{b}^{2}}{\sigma_{1}{ }^{2}}\right]
$$

Keterangan :

$$
\begin{array}{lll}
\mathrm{n} & = & \text { jumlah sampel } \\
\mathrm{X} & = & \text { nilai skor yang dipilih }
\end{array}
$$

Dasar pengambilan keputusan:

Jika $r$ alpha positif, serta $r=0,70$ maka faktor atau variabel tersebut reliabel jika $r$ alpha tidak positif, serta $r<0,70$ maka faktor atau variabel tersebut tidak reliabel.

Data yang diperoleh dari lapangan kemudian di olah dengan menggunakan analisis deskriptif. Analisis deskriptif bertujuan untuk meninjau jawaban responden dari responden terhadap masing-masing pernyataan yang menjadi instrumen penelitian ini. Langkah pertama dalam analisis deskriptif adalah mentabulasikan data yang telah diperoleh dari lapangan kemudian disusun dalam table distribusi frekuensi untuk mengetahui apakah tingkat perolehan nilai (skor) variabel penelitian masuk dalam kategori sangat baik, baik, cukup, tidak baik, sangat tidak baik. Selanjutnya untuk menetapkan peringkat dalam setiap variabel penelitian dapat dilhat dari perbandingan antara skor aktual dengan skor ideal.

Skor aktual diperoleh melalui hasil perhitungan seluruh pendapat responden sesuai klasifikasi bobot yang diberikan (1,2,3,4,dan 5). Sedangkan skor ideal diperoleh melalui nilai tertinggi dikalikan dengan jumlah pernyataan kuesioner dikalikan jumlah responden.

\section{a. Analisis Capital Budgeting}

1) Profitability index adalah metode prediksi kelayakan suatu proyek dengan membandingkan nilai penerimaan bersih dengan nilai investasi. Rumus PI sebagai berikut :

$$
\text { Present Value of Cash Inflows }
$$

$\mathrm{PI}=$

Initial Investment 
Keterangan:

$\begin{array}{lll}\mathrm{CF} & = & \text { Cash Flow } \\ \mathrm{II} & = & \text { Initial Investment }\end{array}$

Suatu investasi akan diterima jika PI-nya lebih besar atau sama dengan satu, dan sebaliknya akan ditolak jika indeks profitabilitasnya lebih kecil dari satu.

2) Payback Period adalah jangka waktu yang diperlukan untuk mengembalikan nilai investasi melalui penerimaan yang dihasilkan oleh proyek investasi tersebut. Dengan demikian, metode ini mengukur waktu pengembalian dana investasi, bukan mengukur profitabilitas dari investasi tersebut. Rumus metode discounted payback period sebagai berikut:

\section{Initial Investment}

$$
\mathrm{DPP}=
$$

\section{Present Value of Annual Net Casli.Inflows}

Suatu usulan proyek investasi akan diterima jika periode pengembalian yang dihasilkan lebih cepat dari yang disyaratkan. Sebaliknya, jika periode pengembalian yang dihasilkan lebih lama dari yang disyaratkan, maka usulan proyek investasi tersebut ditolak.

3) Net Present Value adalah sebuah metode yang dipakai untuk menilai usulan proyek investasi yang mempertimbangkan time value of money sehingga arus kas yang dipakai adalah arus kas yang telah didiskontokan atas dasar biaya modal (cost of capital) perusahaan atau tingkat bunga atau tingkat pengembalian yang dinyatakan rumus Net Present Value adalah sebagai berikut :

$$
\begin{aligned}
& N \mathrm{~N}^{\prime} \mathrm{V}=\frac{C F_{1}}{(1+i)^{1}}+\frac{C F_{2}}{(1-i)^{2}}-\frac{C F_{3}}{(1+i)^{3}}+\cdots \\
& +\frac{C F_{n}}{(1+i)^{n}}-I I \\
& N H^{\prime} V=\sum_{\varepsilon=1}^{n} \frac{C F_{t}}{(1+k)^{2}}-H
\end{aligned}
$$

Keterangan:

$$
\begin{array}{ll}
\text { CFI-3,CFn } & =\text { Cash Flow tahun ke-1,2,3 sampai ke } \mathrm{n} \\
\mathrm{I} & =\text { biaya modal/tingkat bunga } \\
\mathrm{N} & =\text { umur proyek investasi } \\
\text { II } & =\text { Initial Investment }
\end{array}
$$

Keputusan tentang apakah suatu usulan proyek investasi diterima atau ditolak ditentukan oleh nilai NPV-nya. Jika NPV positif, artinya dana yang diinvestasikan dalam proyek tersebut dapat 
menghasilkan PV (Present Value) arus kas lebih tinggi dari PV investasi awal. Sebaliknya, jika NPV negatif artinya dana yang diinvestasikan dalam proyek tersebut dapatpada tingkat bunga tersebut akan sama dengan initialinvestrnent. Rumus IRR adalah sebagai berikut:

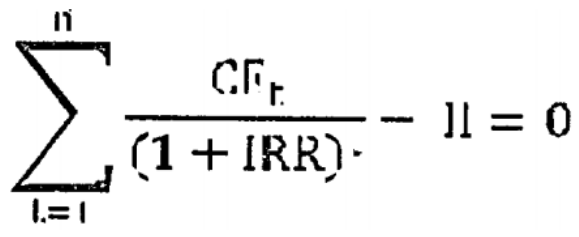

Keterangan:

$\begin{array}{ll}\mathrm{CF} & =\text { Cash Flow } \\ \mathrm{II} & =\text { Initial Investment }\end{array}$

NPV yang positif artinya dana yang diinvestasikan dalam proyek investasi tersebut dapat menghasilkan PV arus kas masuk lebih tinggi daripada PV investasilebih rendah dari PV investasi awal. Dengan dernikian, suatu usulan proyek investasi diterima jika NPV-nya lebih besar dari nol. Sebaliknya suatu usulan proyek investasi ditolak jika NPV-nya lebih kecil dari nol.

\section{1) Inter•nalRate Of Return}

Internal Rate of Return adalah tingkat bunga yang akan menyebabkan NPV sama dengan nol,karena present value cashawal, sehingga IRR-nya lebih tinggi dibandingkan dengan biaya modal atau tingkat suku bunga atau required rate of return. Suatu usulan proyek investasi diterima jika IRR-nya lebih tinggi atau sama dengan biaya modal atau tingkat suku bunga dan atau required rate of return. Sebaliknya, suatu usulan proyek investasi ditolak jika IRR-nya lebih rendah dari biaya modal atau tingkat suku bunga dan atau required rate of return.

\section{HASIL DAN ANALISIS}

Kelayakan investasi Heritage Isola Resort Hotel berdasarkan empat dimensi aspek pemasaran yang diteliti dinyatakan memiliki kelayakan investasi yang baik, dengan nilai skor sebesar $76 \%$ (berada pada interval 68\%-84\%). Berdasarkan dimensinya, seluruh aspek pemasaran dinyatakan dalam kategori baik, dengan skor tertinggi adalah tempat $(80,20 \%)$, selanjutnya adalah produk $(76,50 \%)$, harga $(75,30 \%)$ dan dimensi terakhir adalah promosi (71,50\%). Hasil tersebut menunjukkan bahwa keunggulan Heritage Isola Resort Hotel yang paling utama adalah dari dimensi tempat $(80,20 \%)$, yaitu strategis, mudah dijangkau, tingkat keamanan yang baik dan fasilitas akomodasi yang nyaman. Sedangkan berdasarkan skor terendah yang dicapaipada aspek pemasaran yaitu dimensi Promosi $\mathbf{7 1 , 5 0 \% )}$, menunjukkan perlu adanya kegiatan promosi yang lebih dalam rangka meningkatkan serapan penjualan dalam meningkatkan pendapatan Heritage Isola Resort Hotel.

Kelayakan investasi Heritage Isola Resort Hotel berdasarkan proyeksi keuangan yang diteliti dinyatakan memiliki kelayakan investasi yang baik. Dari beberapa faktor pembentuk keputusan tersebut dan dibantu dengan menggunakan teknik analisis capital budgeting maka didapatkan hasil sebagai berikut: 


\section{Metode Discounted Payback Period (DPP)}

Hasil perhitungan pihak Isola Resort Hotel menggunakan metode Discounted Payback Period menunjukkan bahwa investasi akan kembali setelah 6 tahun 6 bulan 23 hari; sedangkan dari hasil perhitungan penulis dengan metode yang sama didapatkan bahwa investasi akan kembali setelah 8 tahun 2 bulan 18 hari. Berdasarkan analisis diatas ditemukan bahwa pengembalian modal investasi basil perhitungan penulis memang membutuhkan waktu yang lebih lambat, hal ini disebabkan oleh adanya perbedaan hasil perhitungan net cash flow, perbedaan komponen other income,dan komponen cost and expenses yang nilainya lebih rendah dari pihak Isola Resort Hotel. Menurut kriteria penilaian metode discounted payback period adalah rencana investasi yang akan dilakukan berada dalam kriteria layak untuk dilaksanakan.

\section{Metode Net Present Value (NPV)}

Berdasarkan hasil analisis penulis berdasarkan metode net present value didapatkan basil perbandingan dengan nilai selisih sebesar Rp.9.134.519.082,-- Nilai selisih ini muncul sebagai basil selisih perhitungan net present value antara pihak Isola Resort Hotel dan penulis, angka selisih ini disebabkan oleh adanya perbedaan perhitungan basil net cash flow yang dihasilkan kedua belah pihak. Secara keseluruhan basil penilaian metode net present value tersebut maka investasi berada dalam penilaian layak untuk dilaksanakan.

\section{Metode Internal Rate Of Return (IRR)}

Berdasarkan hasil analisis penulis berdasarkan metode internal rate of return didapatkan hasi perbandingan dengan nilai selisih perhitungan sebesar 7.96\%. Nilai ini muncul sebagai hasil selisih perhitunganinterna/ rate of return antara pihak Isola Resort Hotel dan penulis, angka selisih ini muncul disebabkan oleh adanya perbedaan basil perhitungan net cash flow yang dihasilkan kedua belah pihak. Berdasarkan hasil analisis penulis sebelumnya perhitungan internal rate of return dari kedua belah pihak, baik pihak Isola Resort Hotel maupun penulis memiliki basil perhitungan IRR lebih besar dari rate of return yaitu sebesar (12\%) maka hal ini berarti usulan investasi menurut kriteria penilaian metode internal rate of return layak untuk dilaksanakan.

\section{Metode Profitability Index (PI)}

Berdasarkan basil analisis penulis berdasarkan metode profitability index didapatkan hasil perbandingan dengan index selisih sebesar 0,68. Nilaiindex selisih ini muncul sebagai basil perbedaan perhitungan profitability index antara pihak Isola Resort Hotel dan penulis, index selisih ini muncul disebabkan oleh adanya perbedaan net cash flow yang dihasilkan kedua belah pihak. Secara keseluruhan dari penjelasan analisis tersebut maka disimpulkan usulan investasi menurut kriteria penilaian metode profitability index adalah layak untuk dilaksanakan.

\section{SIMPULAN}

Berdasarkan hasil penelitian dan analisis yang telah dilakukan, maka dapat diambil kesimpulan sebagai ben kut:

1. Kajian Isola Resort Hotel dinilai dari aspek pemasaran dapat dinyatakan baik dan diterima. 
2. Kajian Isola Resort Hotel dinilaidari aspek proyeksi keuangan dan kemudian dievaluasi dengan menggunakan teknik capital budgeting dapat dinyatakan balk dan diterima.

Pelaksanaan kegiatan pemasaran, dinilai dalam kategori balk berdasarkan penilaian para responden, tetapi ada beberapa unsur didalamnya yang hams diperbaiki, salah satunya yaitu pelaksanaan kegiatan promosiagar pemasaran Isola Resort Hotel dapat lebih fokus terhadap pangsa pasar business pada saat periode weekdays dan pada saat periode weekend lebih berfokus kepada pencapaian pangsa pasar tourister sehingga lebih banyak lagi potensi tamu yang memutuskan untuk menggunakan jasa akomodasi di Isola Resort Hotel nantinya.

Program promosi lebih diperluas lagi seperti pemasangan iklan dalam website Isola Resort Hotel, majalah bisnis atau surat kabar harian terutama kepada surat kabar/majalah lokal Bandung terlebih dahulu, dan media elektronik juga yang bersifat lokal terlebih dahulu. Akan tetapi pada operasionalperlu dilakukan program jangka dua tahun satnpai tiga tahun promosi yang lebih luas, yaitu pemasangan iklan dalam majalah bisnis atau surat kabar yang sudah bersifat nasional.

Pihak Heritage Isola Resort Hotel sebaiknya mengaplikasikan metode forecast yang lebih tajam dan sesuai dengan teori peramalan pendapatan di masa yang akan datang dengan menggunakan analisis sensitivitas sehingga hasil proyeksi tidak terlalu optimis namun bersifat moderat, hal ini dimaksudkan untuk mengantisipasi apabila terjadi hal-hal yang tidak diharapkan (extra ordinary item) dalam upaya pencapaian target pendapatan di masa mendatang yang telah direncanakan sebagai sumber dana untuk pengembalian investasi.

\section{DAFTAR PUSTAKA}

Alma, Buchari. 2004. Manajemen Pemasaran Dan Pemasaran Jasa. Bandung. Alfabeta.

Cahyono, Bambang Tri. 1996. Metodologi Rise! Bisnis. Jakarta. IPWI.

Chatfield, Robert E. and Dalbor:2005. Hospitality Financial Management. New Jersey. Prantice Hall.

Coltman, Michael M and Jagels. 2004. Hospitality Management Accounting. New York. Van Nostrand Reinhold.

Halim, Abdul. 2005.. Analisis Investasi. Malang. Salemba Empat.

Heizer, Jay dan Ban-y Render. 2006. Operations Management. Eighth Edition. New Jersey. Pearson International Edition.

Kajian Aspek Pemasaran dan Aspek Proyeksi Keuangan dalam Upaya Pengembangan Usaha di Isola Resort Hotel - UPI Bandung

Wishnu Wardhana Hurriyati, Ratih. 2010. Bauran Pemasaran da`n Loyalitas Konsumen. Bandung. Alfabeta.

Husnan, Suad dan Enny Pudjiastuti. 2000. Dasar-Dasar Manajetnen Keuangan. Yogyakarta. AMP YKPN. 